\title{
Assessing the Factors that Cause Poor Quality of Design and Contract Documentation and the Influence on Project Implementation in Ghana
}

\author{
Abu Fatawu ${ }^{1}$, Ibrahim Adamu², Mohammed Awal Sidik ${ }^{3}$ and Moo Fortunatus ${ }^{4}$ \\ 1. Development Office, Wa Technical University, P. O. Box 553, Wa-Ghana. \\ 2. School of applied Science and Technology, Department of Building Technology and Estate \\ Management, Wa Technical University, P. O. Box 553, Wa - Ghana. \\ * Email of corresponding author: aiminis75@yahoo.com
}

\begin{abstract}
Design and contract documentation processes which occur throughout the life cycle of the contract, is often mentioned an area that engenders contractual disputes in Ghana. This paper investigated the factors causing poor quality of design and contract documentation (DCD) and how this impact on successful project implementation in Ghana. It used questionnaire approach as the main method to obtain data which was analyzed using Relative Importance Index (RII) and Kendall's concordance testing. Out of forty factors noted to contribute to DCD deficiencies, six were identified as critical: selection of designers on the basis of lowest price, unwillingness to pay fees commensurate with design services, last minute changes by clients, insufficient design reviews, inadequate clients' briefs, slow payment systems and insufficient or missing input information from the client. To minimize or prevent DCD deficiencies in Ghana's construction industry, the research recommends that briefs are adequate, clear and precise; consultancy fees are commensurate to the required service quality; consultants to ensure adequate review of design and contract documentation with all stakeholders and clients to select consultants based on merits. The measures suggested by the paper are believed to contribute to good quality contract documentation which can consequently improve project implementation in Ghana.
\end{abstract}

Keywords: Contract documentation, Construction projects performance, Quality documentation, Deficient Design.

DOI: $10.7176 / \mathrm{CER} / 12-7-08$

Publication date:July $31^{\text {st }} 2020$

\section{Introduction}

Typical design and contract documentation (DCD) maybe described to consist of design drawings, specifications, bill of quantities/schedule of rates, instructions to tenderers, conditions of the contract, forms of contract as well as other written correspondences and attachments (Rodriguez, 2019; Assaf et al, 2018; Buchan et al., 2003; Cook, 1991). According to Tilley et al. (1999), there is a significant impact on the overall performance and efficiency of construction projects by the quality of design and documentation.

"Designers provide the graphic and written representations, which allow contractors and subcontractors to transform concepts and ideas into physical reality. How effectively and efficiently this transformation occurs depends largely on the quality of the DCD provided" (Tilley and Barton, 1997). This implies that poor and inefficient design and documentation may have a negative effect on the entire project. Whilst ensuring the need for "effective" design, it is also necessary to communicate effectively through documentation, i.e., specifications, drawings, bills of quantities, variation orders, correspondences, etc. (Tilley, 1997). In an ideal situation, contract documentation for construction projects should be complete and error-free and should be able to meet the client's requirements (effective). A case study conducted in the UK on the quality of tender documents by Laryea (2011) revealed that, there have been disputes and claims among contractual parties due to substandard information provided in designs and contract documentation in terms of details, accuracy, adequacy and ambiguity in design drawings, specifications, bills of quantities etc.

ACIF and APCC (2002) also stated that there is a seeming deterioration in the quality of DCD resulting in inadequacies and unascertained costs in the construction process in recent years. According to Tilley (2005b), there is a significant effect on the construction industry's efficiency due to issues regarding DCD quality and as such contributes greatly to rework in reconstruction. This paper investigated the above problems and assessed the extent to which poor quality of DCD affects the performance of construction projects in Ghana. The research specifically sought to:

- $\quad$ Find out the major factors causing poor quality of DCD

- Ascertain how frequent these factors occur in administering construction projects 
- $\quad$ Find out the extent to which these factors affect performance of construction projects

- Establish preventive measures that can be put in place to minimize the deficiencies in design and contract documentation

Since the quality of DCD generated by consultants has a substantial influence on the overall performance and efficiency of construction projects, it is important that issues confronting the quality of design and contract documentation be identified and discussed. Findings could help to improve construction projects delivery. The outcome of this research is intended to inure to the benefit of all contractual parties; all professionals working with clients, contractors and consulting firms.

\section{Research Design and Methodology}

The research was conducted in two stages. First, existing literature was reviewed to highlight causative factors and effects of design and contract documentation deficiencies in different parts of the globe. Secondly, forty factors obtained through the literature was converted into questionnaire and tested in the study area for agreement and severity. This method was used because it is economic in nature, simpler and facilitates quicker turnaround in the collection of data (Cresswell, 2014).

\subsection{Sample Population and Sample Size}

Respondents' selection was limited to clients, D1 contractors and consultants mostly consisting of architects and quantity surveyors located and working in Northern Ghana. Clients approached consisted of entities implementing and managing public construction projects and who are familiar with design documentation processes. The choice of D1 class of building contractors was due to the magnitude of projects they undertake which involve large volumes of DCD that are prone to deficiencies or errors. Snowball sampling technique was adopted in the selection of D1 contractors working on public projects in the region due to the difficulty in accessing data for this category of respondents. The total sample size of all the three categories of respondents (consultants, clients and contractors) was eighty-five (85).

Construction industry Professionals (i.e. architects, civil/structural engineers, quantity surveyors etc.) with an appreciable level of experience working with consulting, construction and client organizations in these regions were surveyed to ascertain the factors affecting the quality of DCD using questionnaires. Clients were chosen because they initiate and promote projects, and hence project successes are of great concern to them. Consultants were also chosen because they produce architectural and structural designs based on the client's initiatives and briefs, quantity surveying services as well as supervision of the construction process. Contractors were also selected because they do the actual execution of projects which have been designed by consultants. Architectural and structural drawings and bills of quantities are the only contract documents that this study focused on.

2.2 Data Analysis Tools

The following statistical techniques were employed for the data analysis:

1. Descriptive Statistics: This was used in computing frequencies and percentages of the background information of the respondents such as category, professional background, years of experience etc. also mean and standard deviation was used where there is a tie in the ranking using RII.

2. Relative Importance Index (RII): $=\frac{\sum W}{(A \times N)}:($ Fugar and Agyakwah-Baah, 2010)

Where: $\mathrm{W}$ is the weighting given to each factor by respondents, ranging from 1 to $5, \mathrm{~A}$ is the highest weight (5) and $\mathrm{N}$ is the number of samples in the study. It was used in analysing the three main objectives of the study as follows:

(i) Ranking the significant factors in terms of the degree of severity.

(ii) Ranking factors to determine the frequency of occurrence.

(iii) Ranking the effects of poor quality DCD to determine the degree of severity on construction projects performance.

(iv) Ranking of the possible remedial methods to ascertain the level of importance of each method.

3. Agreement analysis: A non-parametric statistic known as Kendall correlation coefficient was used for evaluating the level of agreement/similarity between the two sets of rank (Clients and Consultants) to the same set of possible causes of poor quality of design and contract documentation in Northern Ghana. This tool was used to assist the researcher to find out whether there is a trend of agreement among the respondents. 
$W=\left[\frac{\left[\sum_{i=1}^{k}\left(R_{i}-R\right)^{2}\right]}{n\left(n^{2}-1\right) / 12}\right]$

$n\left(n^{2}-1\right) / 12$ is the maximum possible squared deviation i.e. the numerator which will occur if there were perfect agreements among $\mathrm{k}$ sets of ranks and the average rankings were $1,2,3 \ldots \mathrm{n}$;

$R_{i}=$ rank assigned by an individual judge to one factor;

$0.0 \leq W \geq 1.0$

$\mathrm{K}$ is number of sets of ranking (2);

$\mathrm{n}$ is a number of factors to be ranked (40);

$\mathrm{R}$ is an average of the ranks assigned to the nth factor been ranked.

4. Spearman correlation: this is an inferential statistics method and was used to ascertain whether the differences in ranking of the two groups of respondents on the possible methods of preventing deficiencies in design and contract documentation were statistically significant or not.

The research appraised existing literature in the context of contract documentation quality in the construction industry. The essence was to identify the factors influencing the quality of design and contractual documentation, their effects and ways of eliminating or minimizing these effects.

\section{Literature Review}

Quality of Design and Contract Documentation

Designs are normally services rendered by consultants to their clients according to the client's requirements. Quality is also defined in terms of a construction project by Arditi \& Gunaydin (1997) as "meeting the legal, aesthetic and functional requirements of a project". However expressed, quality is obtained if the stated requirements are adequate, and if the completed project conforms to the requirements.

According to Arditi \& Gunaydin (1997), drawings and specifications issued to the contractor by the consultant contain technical information of materials and various components that affect the standard of quality required by the construction. Inconsistencies in drawings and specifications have been a headache in the construction process (Assaf, et al, 2018). The project must be constructible by the contractor contracted to construct it. Construction methods and materials that contractors will be using in the execution of the project must be familiar to the professionals producing the designs. Queensland (2005) maintained that for design and contract documentation to be adequate and of right quality, they should be coherent and explicit, precise, complete and timely.

Causes of Deficient Designs and Documentation

Design deficiency is commonly described by various researchers (Rodriguez, 2019; Assaf et al, 2018; Gatlin, 2013; Abdalaziz, 2009) to include failure to produce an accurate, complete and well-coordinated set of design and construction documentation by a design professional.

Slater and Radford (2012) observed that, some of the difficulties encountered on a site can be traced to design decisions by architects, deficient specifications, as well as erroneous documentation. According to Abdalaziz, (2009), most design deficiencies fall under one of three (3) categories:

1. Conflicting contract information: disagreements between drawings, bill of quantities and specifications.

2. Coordination errors within parties: problems of interference with consultants of other engineering disciplines such as structural, mechanical, electrical, etc.

3. Discrepancies due to technical compliance: non-adherence to the right design guidelines, building codes and specifications.

Major variations may occur if drawings and specifications are inadequate and would ultimately affect the completion of the project. If specifications or drawings are incomplete or unclear, it creates interpretation problems, thereby compromising the quality of the project (Assaf et al., 1996). According to Alarcon and Mardones (1998), three main problems confront the design and construction interface: poor quality design, lack of standards in design and constructability of designs.

Classified under the type of construction document, Dosumu and Adenuga (2013) identified the causes of inaccuracies in contract documents to include the following: 
Table1: Causes of Design Deficiencies

\begin{tabular}{|c|c|c|}
\hline $\mathbf{S} / \mathbf{N}$ & Type of Document & Error/inaccuracy/deficiency/ \\
\hline 1 & Drawings & $\begin{array}{l}\text { i. Missing or deficient input information } \\
\text { ii. Drawings being incomplete } \\
\text { iii. Unsatisfactory planning and design work } \\
\text { iv. Errors in design } \\
\text { v. Professional negligence } \\
\text { vi. Incorrect drawings }\end{array}$ \\
\hline 2 & Specifications & $\begin{array}{l}\text { i. Changes in specifications } \\
\text { ii. Incorrect drawings } \\
\text { iii. Unsatisfactory planning and design work } \\
\text { iv. The experience of the designer }\end{array}$ \\
\hline 3 & Bill of Quantities & $\begin{array}{l}\text { i. Inadequate documentation } \\
\text { ii. Poor communication between the professional and the client } \\
\text { iii. Negligence of the professional. }\end{array}$ \\
\hline 4 & Schedules & $\begin{array}{l}\text { i. Information availability } \\
\text { ii. Professional experience } \\
\text { iii. Inadequate documentation } \\
\text { iv. Inadequate computation }\end{array}$ \\
\hline 5 & Form of Contract & $\begin{array}{l}\text { i. Poor cost control method } \\
\text { ii. Availability of detailed information } \\
\text { iii. Lack of adequate documentation } \\
\text { iv. Long period between tendering and award }\end{array}$ \\
\hline
\end{tabular}

Source: Dosumu and Adenuga, 2013

Love et al (2008) revealed that a number of factors contribute to the incidence of design errors in construction projects. For instance, the pressures from clients on design consultants to provide detailed design documentation within a short time period can result in errors in design.

Effects of Design and Documentation Deficiencies

Available literature identified several adverse effects of design and documentation deficiencies.Oversights and omissions or errors in design, and specification due to the lack of the coordination have culminated to disputes that occur in construction projects (Assah-Kissiedu et al, 2010).

According to Dosumu and Adenuga (2013), design and documentation errors results in serious effects such as projects abandonment, delays, rework, client dissatisfaction, lack of confidence in consultants, frustration of stakeholders, lack of concentration on other projects, discourages investment, and designers profit. In the 
Australian construction industry, it is realized that deficiencies in contract documentation has been steadily increasing and is directly proportional to inefficiency in the construction process (Tilley, 1998). These consequences result in an increase in overall project cost and a reduction in the project quality. Also, according to Queensland (2005), poor quality of design documentation has led to 60 to $90 \%$ of all variations in the construction industry. Similarly, Kikwasi (2013) noted that design changes are considered the topmost cause of delays and interferences in projects delivery in developing countries. Other effects identified by this research include; time extensions, project cost overruns, adverse impact on social life, resource idling, disputes and arbitration. Ismail et al (2012) reported that errors and omissions in the designs were ranked the second most critical factors causing variation orders in construction projects. Also, serious concerns such as rework and wastages occur in projects due to design and construction errors which have effects on project performance and productivity aspects (Palaneeswaran et al., 2007). This is supported by Hwang et al. (2009) who identified omissions/errors in design as the core cause of rework in construction projects and has led to cost increases.

\section{Design Quality Measurement}

Arditi and Gunaydin (1997) explained quality in the construction industry's perspective as the meeting of the requirements of all contractual parties, i.e. client, consultant, and contractor as well as regulatory agencies. The main characteristics of quality include:

1. Satisfying client's requirement in terms of adequacy of function, operation, maintenance, meeting timelines and budget, and life cycle cost.

2. Satisfying the requirement of the design consultant by providing adequate brief.

3. Satisfying the contractor's requirements by providing a well-detailed and accurate tender and contract document.

4. Satisfying the requirements of public regulatory agencies as to the protection of public property, including utilities, environmental concerns, public health and safety, and conformance with relevant laws, regulations, codes and policies.

Improving the Quality of Contract Documentation

For an improvement in the quality of contract documentation, it is necessary to change the way the design process is managed. Darwish (2007) states that at the design phase of projects, the client's requirements should be clearly specified to avoid deficiencies in the design which may result in contract variations during the construction stage. There would be an effective improvement in the overall design and documentation quality if the client and contractor were properly involved at the inception of the design stage. This will enable the consultant to have ample time to rectify and make corrections to any omissions, inaccuracies or ambiguities before the start of the construction process.

Queensland (2005) and ACIF \& APCC (2002) established the following principles and protocols that are anticipated to improve contract documentation quality in the construction industry:

1. Project establishment: clearly defined client's brief comprising of important drivers and considerations such as budgets, functions, and quality.

2. Consultant selection: consultant's fees should be commensurate to the scope of work and experience of the consultant.

3. Team formation and project integration by ensuring that there is a clear understanding of the responsibilities, roles, and obligations by the parties.

4. Quality management system including project implementation and documentation by actively considering the life cycle cost of the project.

5. Consultant's obligations and functions:

i. Advising the project owners on the sufficiency of the brief and the risk associated with poor allowance for proper documentation in both budgets and programs;

ii. Creating designs and documentation, coordination roles within the project team. 
iii. Complying with the code of ethics and professional conduct requirements regarding documentation quality and propose that fees proportionate with the effort involved.

Methods of Preventing DCD Deficiencies

Adherence to project management and organizational practices and creating an atmosphere that allows individuals to learn from their mistakes can help prevent many of the errors that occur in the design and documentation of construction projects (Lopez et al., 2010). To assist in the improvement of overall documentation quality, it was suggested that vast improvement in coordination and management between disciplines should be a requirement (Flantje et al., 2012).

Johansen and Carson (2003) suggested that the most important ideas that require attention are the provision of adequate design time, the need for a working team approach, the quality of clients briefing and a clearly identified competent manager to control the process.

Dosumu and Adenuga (2013) further suggest the under-listed to control the several errors plaguing design and documentation in the construction industry;

- Enhanced partnership between designers and other team members while preparing construction documents.

- Allowing adequate time for the preparation of designs and documentation.

- Clients should use the right procurement methods for construction projects.

- Good and effective communication among the construction project team.

- The use of electronic documents management system is advised.

- There should be effective and efficient project management.

- There should be adequate financial provision.

In an attempt to eliminate design defects, Chong and Low (2006) suggested that designers should be encouraged to adopt and use standards and codes such as British Standards (BS) etc. Designers are also encouraged to abreast themselves with the latest knowledge, ideas and technologies in the industry. They are also advised to develop a file whereby hidden defects could be traced and mistakes avoided in future. The following recommendations were made in a study conducted by Laryea (2011) for the adoption of clients to increase the quality of tender documents. They are:

- Know what you want

- Describe it very clearly

- Do not assume that the other person knows what you want

- Tell them what you want

- $\quad$ Do not change your mind

- Allow a sensible tender period

- Be sensible about risk sharing

Asamoah and Nyako (2013) recommended that a comprehensive review of the design and contract documents is done by the design team at all times. There should be an improvement in communication between the contractual parties. Also, before the works start on site it is required by all parties to do feasibility studies and adequate planning. The implementation of design audits, design reviews and verifications, provision of adequate time for designers to produce documentation and using computer aided design (CAD) applications will help minimize the impact of errors before documentation is distributed for tender though this will not prevent errors from occurring (Reason, 2002) and (Love et al., 2008). 
In their study, Aagaard and Pedersen (2013) emphasized the need for a review and control of documentation as a means of integrating tasks in the design and construction phases. It is also required that special attention is given to the review and control of the use of ICT in modeling and structural design. According to Love et al. (2008), Building information modeling (BIM) will considerably increase the performance of projects if it used as an enabler compared with other key strategic and process improvements that have been acknowledged. Penttila (2006) stated that BIM makes it explicit the interdependence that exists between architectural layout, mechanical, structural, electrical, and hydraulic services by technologically coupling project organizations.

\section{Fieldwork Discussions}

The professionals constituting the respondents in that category comprises of architects (19\%), civil/structural engineers $(21 \%)$, quantity surveyors $(42 \%)$, clerks and others $(17 \%)$. The research revealed that over fifty percent of the respondents have executed or is executing both private and public projects. Also, a large proportion of the respondents have experiences of between 5 to 15 years in the industry.

Over $96 \%$ of the respondents stated that they had encountered a problem regarding design and documentation deficiency or error in construction projects at one point or another in their professional career. Only a very small proportion of the respondents $(3.85 \%)$ answered to the contrary. There is, therefore, a clear indication that, there indeed exist deficiencies in construction projects designs and documentation hence a critical issue that requires attention.

\subsection{Factors Causing Design and Contract Documentation Deficiencies}

Table 2: Factors Causing Design and Contract Documentation Deficiencies by clients and Consultants

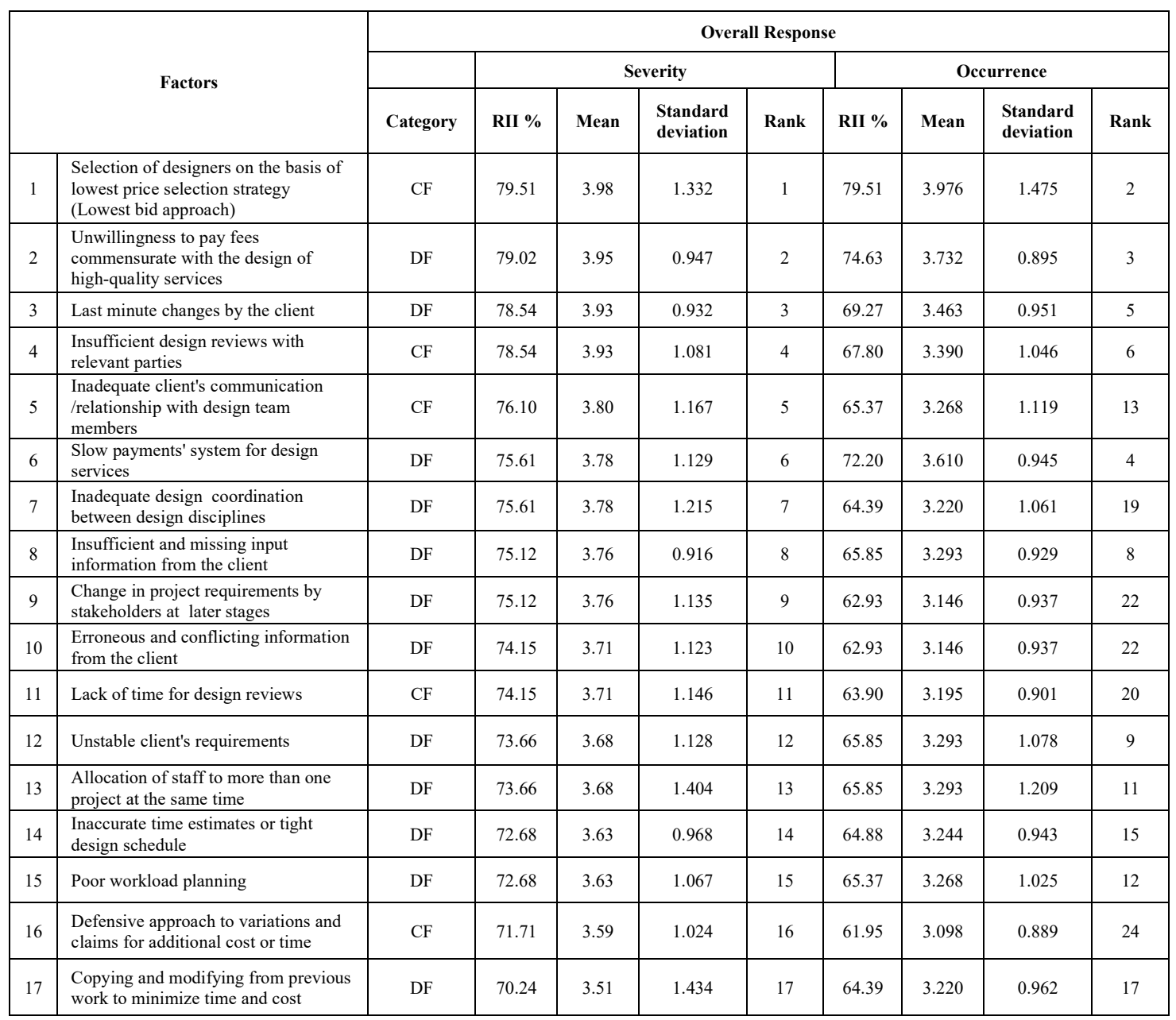




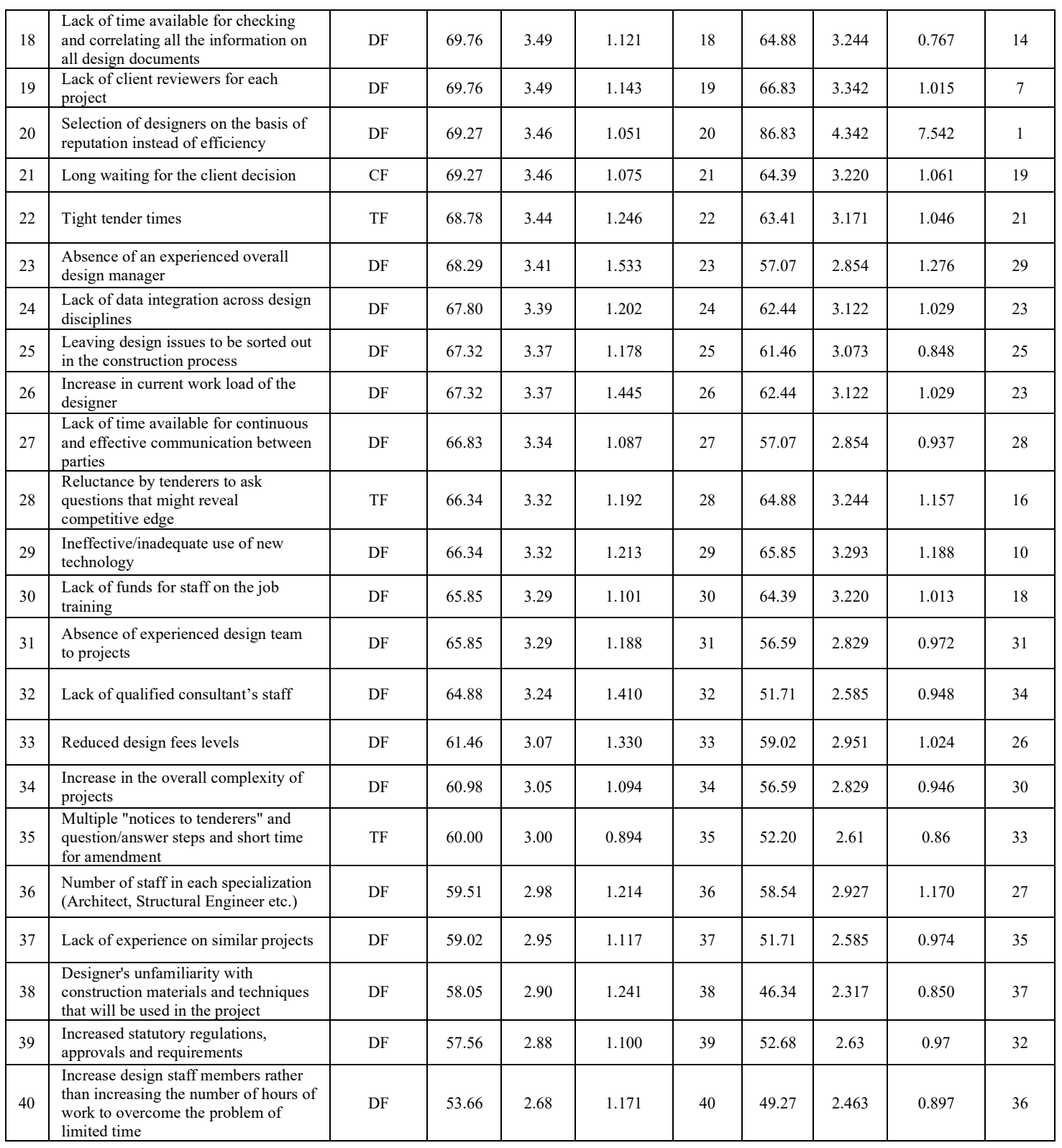

Source: Field work, 2018

\section{Most Severe Factors}

After evaluating the factors from the clients and consultants groups of respondents, the ten (10) most severe factors causing DCD deficiencies in Northern Ghana, based on agreed rankings, were identified as shown in table 3 below. 
Table 3: Most Severe Factors Agreed by Clients and Consultants.

\begin{tabular}{|c|c|c|c|c|c|c|c|c|c|c|c|}
\hline & & & & & & & Severi & & & & \\
\hline & & & & Clients & & & isultan & & Ove & Il Resp & \\
\hline & ost Severe Factors & $\begin{array}{l}\text { Categor } \\
\mathbf{y}\end{array}$ & $\stackrel{\partial^{\circ}}{\underline{a}}$ & 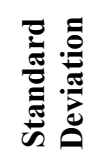 & 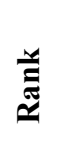 & $\stackrel{\partial^{\theta}}{\underline{\underline{a}}}$ & 总 & 气્ય & $\stackrel{\ominus}{\stackrel{0}{a}}$ & 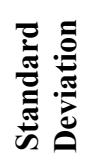 & 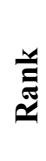 \\
\hline 1 & $\begin{array}{l}\text { Selection of } \\
\text { designers on the } \\
\text { basis of lowest price } \\
\text { selection (lowest bid } \\
\text { approach) }\end{array}$ & $\mathrm{CF}$ & 92 & 0.966 & 1 & 75.48 & 1.383 & 10 & 79.51 & 1.332 & 1 \\
\hline 2 & $\begin{array}{l}\text { Unwillingness to pay } \\
\text { fees commensurate } \\
\text { with the design of } \\
\text { high-quality services }\end{array}$ & DF & 82 & 0.738 & 6 & 78.06 & 1.012 & 2 & 79.02 & 0.947 & 2 \\
\hline 3 & $\begin{array}{l}\text { Last minute changes } \\
\text { by the client }\end{array}$ & DF & 88 & 0.516 & 3 & 75.48 & 0.990 & 7 & 78.54 & 0.932 & 3 \\
\hline 4 & $\begin{array}{l}\text { Insufficient design } \\
\text { reviews } \\
\text { relevant parties }\end{array}$ & $\mathrm{CF}$ & 80 & 1.287 & 11 & 77.42 & 1.024 & 4 & 78.54 & 1.081 & 4 \\
\hline 5 & $\begin{array}{l}\text { Inadequate client's } \\
\text { communication } \\
\text { /relationship with } \\
\text { design team } \\
\text { members } \\
\end{array}$ & $\mathrm{CF}$ & 74 & 1.160 & 18 & 76.77 & 1.186 & 6 & 76.10 & 1.167 & 5 \\
\hline 6 & $\begin{array}{l}\text { Slow payments' } \\
\text { system for design } \\
\text { services }\end{array}$ & DF & 72 & 1.075 & 20 & 76.77 & 1.157 & 5 & 75.61 & 1.129 & 6 \\
\hline 7 & $\begin{array}{l}\text { Inadequate design } \\
\text { coordination } \\
\text { between design } \\
\text { disciplines }\end{array}$ & DF & 76 & 1.135 & 16 & 75.48 & 1.257 & 8 & 75.61 & 1.215 & 7 \\
\hline 8 & $\begin{array}{l}\text { Insufficient and } \\
\text { missing input } \\
\text { information from } \\
\text { the client }\end{array}$ & DF & 66 & 1.059 & 27 & 78.06 & 0.831 & 1 & 75.12 & 0.916 & 8 \\
\hline 9 & $\begin{array}{l}\text { Change in project } \\
\text { requirements by } \\
\text { stakeholders at later } \\
\text { stages }\end{array}$ & DF & 90 & 0.527 & 2 & 70.32 & 1.180 & 16 & 75.12 & 1.135 & 9 \\
\hline 10 & $\begin{array}{l}\text { Erroneous and } \\
\text { conflicting } \\
\text { information from the } \\
\text { client }\end{array}$ & DF & 80 & 1.054 & 9 & 72.26 & 1.145 & 12 & 74.15 & 1.123 & 10 \\
\hline
\end{tabular}

Source: Field work, 2018

As contained in table 3, the research revealed that the selection of designers on the basis of lowest price strategy (lowest bid approach) is the number one cause of design and documentation problems in the study area. Though clients and consultants groups rated it different in terms of rankings ( $1^{\text {st }}$ and $10^{\text {th }}$ respectively), both agreed that the selection process is not appropriate. They contend that it is often driven by price rather than competence required for high level designs. This implies that the lowest bid strategy in the selection of consultants can be detrimental to the delivery quality of DCD in the sense that it might lead to the selection of incompetent consultants.

The unwillingness of clients to pay fees to correspond with the design of high-quality services was noted to be one of the most severe factors causing poor DCD quality in Northern Ghana. During the study, it was revealed that 
clients are the offenders or perpetrators of this phenomenon. Interestingly, the clients themselves asserts it to be a contributory factor to design and contract documentation problem. Consultants were of the view that the fees they receive from clients are not good enough to motivate their staff to put out their best performance to prevent deficiencies in DCD.

Also, late changesby clients were identified as another causative factor that adversely affect design and contract documentation. This client-related phenomenon which was agreed to by all respondent groups gave an indication that clients are aware of the consequences of late changes to the design and documentation process. Insufficient design reviews with relevant parties was one of the important factors causing design and contract documentation problems. This factor is consistent with Dosumu and Iyagba (2013) who observed that lack of reviews in design, constructability and value engineering were among the significant factors causing errors in contract documents.

In addition, the research revealed that inadequate client's communication/briefs with design team members have severe consequences on DCD. This factor was identified as severe by consultants who are particularly affected by the ineffective and poor briefs by clients. When communication is effective, there is coordination and as such, deficiencies that would have resulted due to this factor are preventable.

Other causative factors identified amongst the top ten included slow payment process by clients, inadequate design coordination between design disciplines, erroneous and conflicting information from the client.

\subsection{Effects of Poor Design and Contract Documentation on Project Performance}

Table: 4 shows the Relative Importance Indices (RII) and the rankings of the severity level the various effects of design and documentation deficiency on the performance of construction projects in Northern Ghana by the various respondents. These are discussed according to their rankings as follows.

Table 4: Effects of DCD Deficiencies on Project performance

\begin{tabular}{|c|c|c|c|c|c|c|c|c|c|}
\hline \multirow{3}{*}{\multicolumn{2}{|c|}{ Effects }} & \multicolumn{8}{|c|}{ Severity Level of Effect on Performance } \\
\hline & & \multicolumn{2}{|c|}{ Clients } & \multicolumn{2}{|c|}{ Consultants } & \multicolumn{2}{|c|}{ Contractors } & \multicolumn{2}{|c|}{ Overall Response } \\
\hline & & RII\% & Rank & RII \% & Rank & RII \% & Rank & RII \% & Rank \\
\hline 1 & Projects abandonment & 90 & 1 & 87.10 & 1 & 96.36 & 1 & 89.62 & 1 \\
\hline 2 & Delays (Time overrun) & 88 & 2 & 86.45 & 2 & 90.91 & 3 & 87.69 & 2 \\
\hline 3 & Cost overrun & 84 & 4 & 84.52 & 3 & 92.73 & 2 & 86.15 & 3 \\
\hline 4 & Payment claims & 86 & 3 & 83.23 & 4 & 87.27 & 4 & 84.62 & 4 \\
\hline 5 & Variation/Change orders & 82 & 5 & 76.13 & 6 & 85.45 & 5 & 79.23 & 5 \\
\hline 6 & Suspension of works & 76 & 7 & 79.35 & 5 & 78.18 & 9 & 78.46 & 6 \\
\hline 7 & Client/owner dissatisfaction & 72 & 9 & 72.26 & 7 & 81.82 & 7 & 74.23 & 7 \\
\hline 8 & Disputes (Conflicts) among parties & 80 & 6 & 68.39 & 9 & 80.00 & 8 & 73.08 & 8 \\
\hline 9 & Rework & 66 & 10 & 70.97 & 8 & 83.64 & 6 & 72.69 & 9 \\
\hline 10 & Arbitration/Litigation & 74 & 8 & 66.45 & 11 & 74.55 & 11 & 69.62 & 10 \\
\hline 11 & Loss of confidence in consultants & 64 & 11 & 67.74 & 10 & 76.36 & 10 & 68.85 & 11 \\
\hline
\end{tabular}

Source: Field work, 2018

From table 4, there is an agreement between all the respondents, that projects abandonment had much impact on the performance of construction projects in Northern Ghana which was ranked $1^{\text {st }}$ by all with an overall RII of $89.62 \%$. This means that projects are usually abandoned and are brought to a halt and there are cost and time implications. Defective design and documentation was also considered to result in delays (time overruns) in the delivery of construction projects. This was ranked $2^{\text {nd }}$ by both client and consultants with RIIs of $88 \%$ and $86.45 \%$ respectively though on the part of contractors it came $3^{\text {rd }}$ with a RII of $90.91 \%$. This is considered to have negatively influenced the time performance of public projects in Northern Ghana and this usually will trigger cost increases on projects. Interestingly, both the $1^{\text {st }}$ and $2^{\text {nd }}$ overall rankings agree with the work of Dosumu and Adenuga (2013) in construction industry.Other effects identified through the research as presented in table 4 included cost overruns, contractual claims with their concomitant issues, variations orders, suspension of works, client/owner dissatisfaction, contractual disputes, arbitrations/litigations and sometimes loss of confidence in consultants.

\section{Agreement Analysis}

A non-parametric statistic known as Kendall's coefficient of concordance aids in evaluating the level of agreement between the two (Clients and Consultants) sets of ranks to the same set of possible causes of poor quality of design and contract documentation in Northern Ghana. This tool assists the researcher to find out whether there is a trend of agreement among the respondents on the 40 factors. 
This range $0.0 \leq W \geq 1.0$ shows the level of agreement among the Clients and Consultants. The concordance coefficients are computed by using data in table 5 .

Table 5: Showing Kendall’s Rank of Concordance Coefficient

\begin{tabular}{|c|c|c|c|}
\hline Respondents' Category & Clients & Consultants \\
\hline \multirow{2}{*}{ Clients } & Severity & 1 & 0.232 \\
\cline { 2 - 4 } & Occurrence & 1 & 0.238 \\
\hline \multirow{3}{*}{ Consultants } & Severity & 0.232 & 1 \\
\cline { 2 - 4 } & Occurrence & 0.238 & 1 \\
\hline
\end{tabular}

From table 5, W is 0.232 and 0.238 respectively for severity and occurrence. These indicate a fair level of agreements among the Clients and Consultants in their ranking of the factor in terms of severity and occurrence since they are greater than zero (0) hence there is no bias on how the ranking of the factors.

4.3 Preventive Methods for Design and Contract Documentation Deficiencies

A question on proposed methods of preventing or minimizing the deficiencies in design and contract documentation processes produced the responses illustrated in table 6 . These responses were also ranked using RII in line with the methodology of the research.

Table 6: Preventive Methods for Each Group of Respondents

\begin{tabular}{|c|c|c|c|c|c|c|c|}
\hline \multirow{3}{*}{\multicolumn{2}{|c|}{ Preventive Methods }} & \multicolumn{6}{|c|}{ Importance } \\
\hline & & \multicolumn{2}{|c|}{ Clients } & \multicolumn{2}{|c|}{ Consultants } & \multicolumn{2}{|c|}{ Overall Response } \\
\hline & & RII\% & Rank & RII\% & Rank & RII\% & Rank \\
\hline 1 & Effective communication between all parties & 98 & 1 & 94.84 & 1 & 95.61 & 1 \\
\hline 2 & $\begin{array}{l}\text { Adherence to established codes and standards } \\
\text { in the industry. }\end{array}$ & 90 & 5 & 93.55 & 2 & 92.68 & 2 \\
\hline 3 & $\begin{array}{l}\text { Willingness to spend sufficient time and } \\
\text { money in project planning and design }\end{array}$ & 92 & 4 & 91.61 & 3 & 91.71 & 3 \\
\hline 4 & $\begin{array}{l}\text { Continuing involvement of client in the } \\
\text { design management }\end{array}$ & 96 & 2 & 88.39 & 6 & 90.24 & 4 \\
\hline 5 & Cooperation among project team & 82 & 8 & 90.97 & 4 & 88.78 & 5 \\
\hline 6 & $\begin{array}{l}\text { Selection of service providers on the basis of } \\
\text { value and competence }\end{array}$ & 94 & 3 & 86.45 & 9 & 88.29 & 6 \\
\hline 7 & $\begin{array}{l}\text { Implementation of quality management } \\
\text { systems }\end{array}$ & 88 & 6 & 87.10 & 8 & 87.32 & 7 \\
\hline 8 & $\begin{array}{l}\text { Continuing professional development for } \\
\text { staff in industry }\end{array}$ & 84 & 7 & 87.74 & 7 & 86.83 & 8 \\
\hline 9 & $\begin{array}{l}\text { Payment of design fees commensurate } \\
\text { withdesign services }\end{array}$ & 74 & 12 & 90.32 & 5 & 86.34 & 9 \\
\hline 10 & $\begin{array}{l}\text { Encourage the role of technology in projects } \\
\text { delivery by all stakeholders }\end{array}$ & 80 & 9 & 85.16 & 11 & 83.90 & 10 \\
\hline 11 & $\begin{array}{l}\text { Identification and analysis of all risks and } \\
\text { uncertainty in project }\end{array}$ & 78 & 10 & 84.52 & 12 & 82.93 & 11 \\
\hline 12 & $\begin{array}{l}\text { Frequent training and retraining of } \\
\text { stakeholders on how to ensure appropriate } \\
\text { and quality design and documentation. }\end{array}$ & 66 & 15 & 85.81 & 10 & 80.98 & 12 \\
\hline 13 & $\begin{array}{l}\text { Framing contracting arrangement around } \\
\text { goodwill and fair dealings in an open } \\
\text { environment }\end{array}$ & 76 & 11 & 81.29 & 13 & 80.00 & 13 \\
\hline 14 & $\begin{array}{l}\text { Adoption of lean production principles to } \\
\text { design management }\end{array}$ & 68 & 14 & 79.35 & 14 & 76.59 & 14 \\
\hline 15 & $\begin{array}{l}\text { Early involvement of contractor in the design } \\
\text { process. }\end{array}$ & 72 & 13 & 76.77 & 15 & 75.61 & 15 \\
\hline
\end{tabular}


Spearman Correlation of Preventive Methods

This is an inferential statistics method and was used to ascertain whether the differences in ranking of the two groups of respondents on the possible methods of prevention statistically significant. Using the rankings of the clients and consultants, the correlation coefficients are calculated and the results are as shown in table 7 below.

Table 7: Ranks Correlation Coefficient

\begin{tabular}{|l|l|l|}
\hline & Clients & Consultants \\
\hline Clients & 1 & 0.693 \\
\hline Consultants & 0.693 & 1 \\
\hline
\end{tabular}

Source: Field work, 2018

The correlation coefficient for the 15 remedial methods for both clients and consultants is 0.693 as illustrated in table 7 . This connotes a high agreement on the rankings by the respondent groups on the ways of preventing or minimizing design and documentation deficiency in Northern Ghana.

\section{Conclusion and Recommendation}

The paper identified forty factors that cause deficiencies in design and contract documentations. These factors were tested through questionnaire on respondents and the results confirmed earlier researchers' assertion on the subject. However, ten (10) of these factors were classified as the main causes in terms of severity and frequency of occurrence out of which six are said to be critical. These include selection of designers on the basis of lowest price strategy (lowest bid approach), unwillingness to pay fees commensurate with the design of high-quality services, last minute changes by the client, insufficient design reviews with relevant parties, slow payment system for design services, and insufficient and missing input information from the client. To minimize or prevent design and documentation deficiencies in Ghana's construction industry, the research recommends that clients must ensure adequate, clear and precise contract briefs. Clients are also to ensure that consultancy fees are commensurate to the required service quality. They must also ensure that the selection of consultants is based on merits and not necessarily on lowest bidder approach. Consultants should make sure there is an adequate review of design and contract documentation with all stakeholders involved. The research further recommends that prompt changes should be tolerated if the need be as well as ensuring timely and regular payments for design service providers.

\section{References}

Aagaard, N. \& Pedersen, E.S., (2013), "Failure and documentation of building structures", In CIB World Building Congress.

Abdalaziz, S.,(2009), "Factors Affecting the Quality of Design and Contractual Documents in Gaza Strip", Islamic University of Gaza, Unpublished Thesis.

Abdallah, A., Hassanain, M., Assaf, S. A. (2018), "Assessment of the Consequences of Deficiencies in Design Documents in Saudi Arabia", Architectural Engineering and Design Management, 15(8), pp. 1-15.

ACIF \& APCC, (2002). Improving Project Documentation- A Guide To Improve Current Practice,

Alarcon, L.F. \& Mardones, D.A., (1998), "Improving the Design-Construction Interface”, In Proceedings of the 6th Annual Meeting of the International Group for Lean Construction, pp. 1-12.

Arditi, D. \& Gunaydin, H.M., (1997), “Total quality management in the construction process", International Journal of Project Management, 15(4), pp. 235-243.

Asamaoh, R.O. \& Nyako, K.O., (2013). Variation Determinants in Building Construction : Ghanaian Professionals Perspective. Journal of Construction Engineering and Project Management, 3(4), pp. 20-25.

Assaf, S., Al-Hammad, A.-M. \& Al-Shihah, M., (1996). Effects of Faulty Design and Construction on Building Maintenance. Journal of Performance of Constructed Facilities, 10(4), pp.171-174.

Assah-Kissiedu, M., Fugar, F.D.K. \& Badu, E., (2010), “Triggers of Disputes within the Ghanaian Construction Industry”, In Proceedings 5th Built Environment Conference (Vol. 18, p. 20).

Chong, W.-K. \& Low, S.-P., (2006), “Latent Building Defects: Causes and Design Strategies to Prevent Them”, 
Journal of Performance of Constructed Facilities, 20(3), pp. 213-221.

Creswell, J.W., (2014), "Research Design: Qualitative, Quantitative and Mixed Methods Approaches", 4th ed., Los Ageles, London, Singapore, Washinton DC: SAGE.

Darwish, M.I., (2007), "Factors Affecting Design Documentation Quality in Construction Industry", Construction Contracting Administration.

Dosumu, O.. \& Iyagba, R., (2013), “An Appraisal of Factors Responsible for Errors in Nigerian Construction Documents", Ethiopian Journal of Environmental Studies and Management, 6(1), pp. 49-57.

Dosumu, O.S. \& Adenuga, O.A., (2013), "Causes , effects and remedies of errors in Nigerian construction documents", Organization, Technology and Management in Construction. An International Journal, 5(1), pp. 676-686.

Ezeldin, A. S. \& Abu-Ghazala, H., (2007), "Quality Management System for Design Consultants: Development and Application on Projects in the Middle East", Journal of Management in Engineering, 23(2), pp. 75-87.

Fellows, R.F. \& Liu, A., (2008), "Research Methods for Construction”, 3rd ed., Oxford, United Kindom: WileyBlackwell.

Flentje, C.,Zuo, J., Jin, X.H., \& Xia, B., (2012), "Comparing the effect of inadequate documentation to the cost management \& tendering processes in Managing Contractor \& Fixed Lump Sum Contracts in Australia", In ICEC IX World Congress. pp. 114.

Fugar, F.D.K. \& Agyakwah-Baah, A.B., (2010), "Delays in Building Construction Projects in Ghana", Australasian Journal of Construction Economics and Building, 10(1), pp. 103-116.

Gatlin, B.F., (2013), "Identifying and Managing Design and Construction Defects", Navigant Consulting Inc, Construction Insight from Hindsight, pp. 1-11. Available at: http://www.navigant.com

Hwang, B., Thomas, S. R., Haas, C.T., \& Caldas, C.H., (2009), "Measuring the Impact of Rework on Construction Cost Performance", Journal of Construction Engineering and Management, 135(3), pp. 187-198.

Ismail, A., Pourrostam, T., Soleymanzadeh, A., \& Ghouyounchizad, M., (2012), "Factors Causing Variation Orders and their Effects in Roadway Construction Projects", Research Journal of Applied Sciences, Engineering and Technology, 4(23), pp. 4969-4972.

Johansen, E. \& Carson, J., (2003), "Improving the effectiveness of the building design management process in the UK”, In 19th Annual ARCOM Conference. pp. 151-160.

Kikwasi, G., (2013), "Causes and effects of delays and disruptions in construction projects in Tanzania", Australasian Journal of Construction Economics and Building, 1(2), pp. 52-59.

Laryea, S., (2011), "Quality of tender documents: case studies from the UK", Construction Management and Economics, 29(3), pp. 275-286.

Long, R.J., (2011), “Defective and Deficient Contract Documents”, Long International Inc., (303), pp. 1-33.

Lopez, R., Love, P. E. D., Edwards, D.J., \& Davis, P. R., (2010), “Design Error Classification, Causation, and Prevention in Construction Engineering”, Journal of Performance of Constructed Facilities, 24(4), pp. $399-408$.

Love, P.E.D., Edwards, D. J., \& Han, S., Goh, Y. M., (2011a), "Design error reduction: toward the effective utilization of building information modeling”, Research in Engineering Design, 22(3), pp. 173-187.

Love, P.E.D., Edwards, D.J. \& Irani, Z., (2008), "Forensic project management: An exploratory examination of the causal behavior of design-induced rework", IEEE Transactions on Engineering Management, 55(2), pp. 234 247.

Mclennan, A. \& Parminter, T., (2004), "Declining Standards of Project Documentation Quality In The Building \& Construction Industry: A Major Challenge For All Stakeholders”, In Clients Driving Innovation International Conference. pp. 1-15.

Naoum, S.G., (2007), "Dissertation Research \& Writing for Construction Students", 2nd ed., Oxford, United Kindom: Butterworth-Heinemann.

Palaneeswaran, E., Ramanathan, M. \& Tam, C., (2007), “Rework in Projects: Learning from Errors”, Surveying 
and Built Environment, 18(2), pp. 47-58.

Penttilä, H., (2006), "Describing the changes in architectural information technology to understand design complexity and free-form architectural expression", ITcon, 11(January), pp. 395-408.

Queensland, (2005), "Getting It Right The First Time: A plan to reverse declining standards in project design documentation within the building and construction industry", Engineers Australia Report,

Reason, J.T., (2002), "Combating omission errors through task analysis and good reminders", Qual. Saf. Health Care, 11, pp. 40-44.

Rodriguez, J. (2019), “10 Essential Contract Documents for Construction Projects: Protection for Contractor and Client”, Available https://www.thebalancesmb.com contract-documents-for-every-construction-project-844919

Sambasivan, M. \& Soon, Y.W., (2007), "Causes and effects of delays in Malaysian construction industry", International Journal of Project Management, 25(5), pp. 517-526.

Slater, R. \& Radford, A., (2012), "Perceptions in the Australian building industry of deficiencies in architects' design documentation and the effects on project procurement", Australasian Journal of Construction Economics and Building, 8(1), pp. 23-33.

Tilley, P.A., (1997), “Causes, Effects and Indicators of Design and Documentation Deficiency”, In Proceedings of the First International Conference on Construction Industry Development: Building the Future Together, Singapore. pp. 388-395.

Tilley, P.A., (2005a), "Design and Documentation Quality Problems - A Lean Thinking Opportunity", In Proceedings of the International SCRI Symposium, Salford, UK. pp. 12-13.

Tilley, P.A., (2005b), "Lean Design Management - A New Paradigm for Managing the Design and Documentation Process to Improve Quality", In Proceeding IGLC - 13. pp. 23-35.

Tilley, P.A., McFallan, S.L. \& Sinclair, R.G., (2002), "Improving Design and Documentation Quality", CIB Report, pp. 361-380.

Tilley, P.A., McFallan, S.L. \& Tucker, S.N., (1999), "Design and Documentation Quality and Its Impact on the Construction Process" In CIB W55 \& W65 Joint Triennial Symposium, Customer Satisfaction: A focus for research and Practice, Cape Town.

Tilley, P.A., Wyatt, A. \& Mohamed, S., (1997), "Indicators of design and documentation deficiency", In IGLC-5: Proceedings of the Fifth Annual Conference of the International Group for Lean Construction. pp. 1-14.

Tilley, P.A. and Barton, R., (1997), "Design and Documentation Deficiency - Causes and Effects”, In Proceedings of the First International Conference on Construction Process Reengineering, Gold Coast, Australia. pp. 703712.

Zidan, A., (2013), "Factors Affecting Design Documentation Quality in Construction Industry", Damascus University Journal, 29(2), pp. 47-48. 